\title{
Semantik dan netnografi sebagai pendekatan penelitian untuk perancangan kembali (redesign) sebuah produk
}

\author{
Sumartono* \\ Program Studi Desain Produk, Fakultas Seni Rupa, Institut Seni Indonesia Yogyakarta, Indonesia
}

\begin{abstract}
This article discusses three research approaches that can be used as a basis for redesigning a product. These three approaches are not all related because netnography is usually associated with ethnography, a well-known approach in anthropology. Although some of the examples given here are rather simple, in its limitations, it is expected that this article is useful for those who want to use these three approaches to redesigning a product.
\end{abstract}

Key words: netnografi, semantic, redesign

\begin{abstract}
Abstrak
Artikel ini mendiskusikan tiga pendekatan penelitian yang bisa digunakan sebagai dasar untuk perancangan kembali sebuah produk. Tiga pendekatan ini tidak semuanya berhubungan karena netnografi biasanya dikaitkan dengan etnografi, sebuah pendekatan yang terkenal dalam anthropology. Meskipun beberapa contoh yang diberikan di sini agak sederhana, dalam keterbatasannya, diharapkan artikel ini bermanfaat bagi mereka yang ingin menggunakan tiga pendekatan ini untuk perancangan kembali sebuah produk.
\end{abstract}

Kata kunci: netnografi, semantik, redesain

\section{Pendahuluan}

Charles W. Morris membagi semiotika menjadi 'sintaktik', 'semantik', dan 'pragmatik'. Pembagian semiotika menjadi tiga ini dipengaruhi oleh pemikiran Charles S. Peirce yang mengembangkan konsep trikotomi-trikotomi. Menurut Noth, pembagian semiotika menjadi tiga bagian oleh Morris itu berasal dari pembagian semiotika oleh Peirce menjadi tiga bagian, yaitu 'tata bahasa murni' (pure grammar), 'logika sebenarnya' (logic proper), dan 'retorika murni' (pure rethoric) (Nöth, 1995). Semantik (kajian tentang makna), sering dianggap sebagai salah satu cabang semiotika, tetapi semantik juga dianggap sebagai pendahulu semiotika modern.

Semiotika Morris bertujuan menerangkan hubungan antara sintaktik, semantik, dan pragmatik. Sintaktik semiotik adalah studi tentang hubungan antar tanda dengan tanda yang lain. Hubungan antara tanda, objek (denotatum), dan interpretant disebut semantik. Sementara itu hubungan antara tanda dan pemakaian tanda disebut pragmatik. Dalam semantik, interpretasi terhadap tanda tidak pernah berakhir. Hal ini tentu sangat menarik dalam proses penafsiran makna. Tidak ada yang lebih steril daripada tetap tidak beranjak dari sintaksis (Zoest, 1993).

Dalam penelitian semiotika jenis ini, memang semantik lebih banyak dibahas karena menyangkut penafsiran makna. Sejauh ini orang dengan mudah bisa menemukan pembahasan tentang semantik produk dalam buku, artikel, atau internet. Tulisan ini akan membahas tentang semantik sebagai pendekatan penelitian di mana hasil penelitian ini kemudian digunakan untuk merancang kembali atau re-desain (redesign) sebuah produk agar lebih baik hasilnya sehingga diharapkan bisa disukai oleh lebih banyak pengguna. Ada tiga pendekatan yang akan dibahas dalam tulisan ini, yaitu pendekatan kategorisasi semantik, pendekatan 'semantik diferensial', dan pendekatan netnografi. Ketiga pendekatan ini tidak sepenuhnya berhubungan karena pendekatan

\footnotetext{
* Koresponden penulis e-mail: tono2maret@yahoo.com
} 
netnografi biasanya dikaitkan dengan pendekatan etnografi, sebuah pendekatan yang popular dalam penelitian antropologis.

Selain pendekatan semantik, pendekatan netnografi juga bisa dimanfaatkan untuk merancang kembali sebuah produk agar lebih baik hasilnya sehingga diharapkan bisa disukai oleh lebih banyak pengguna. Netnografi adalah semacam etnografi yang cara pengumpulan datanya tidak dilakukan dengan menemui partisipan di lapangan tetapi dengan menjaring pendapat partisipan lewat internet.

\section{Pembahasan}

Tiga pendekatan tersebut dibahas satu per satu secara lebih detil di bagian berikut.

\section{Pendekatan Kategorisasi Semantik}

Pendekatan kategorisasi semantik yang dibicarakan di sini adalah sebuah pendekatan lama yang dirumuskan oleh C. Burnette dan dipengaruhi oleh semantik naratif, sebuah wilayah aktualisasi nilai-nilai semantik. Dalam hal ini rumusan kategorisasi semantik pernah juga dikemukakan oleh Greimas dan Courtes (Nöth, 1995), meskipun tidak mendetail seperti rumusan C. Burnette. Untuk penelitian menggunakan pendekatan kategorisasi semantik, pendekatan Burnette ini bukanlah satu-satunya, masih ada pendekatan-pendekatan semantik lain yang juga bisa digunakan, tergantung kasus yang diteliti. Kategori-kategori tersebut adalah sebagai berikut (Burnette, 1994):

a. Semantik Emosional (emotional Semantics): makna berasal dari pengalaman yang diingat, misalnya keadaan tanpa cita rasa, kesenangan, kesukaan, sebuah pengalaman estetik, jatuh di masa kecil, dan lain-lain.

b. Semantik empiris (empirical semantics): makna berasal pengalaman langsung: silau karena cahaya, sebuah wajah baru, sebuah warna, sebuah benda lunak, dan lain-lain.

c. Semantik kognat (cognate semantics) : makna berasal dari asosiasi abstrak, misalnya mobil sebagai binatang, mata sebagai kamera, mobil sebagai kereta tanpa kuda, dan lain-lain.

d. Semantik kontekstual (contextual semantics): makna berasal dari situasi yang ditunjuk berdasarkan orientasi, pengelompokanpengelompokan, berbagai hal, interaksi-interaksi, dan komunikasi-komunikasi, dan lain-lain.

e. Semantik fungsional (functional semantics): makna berasal dari kegiatan membuat, mengerjakan, menggunakan terkait dengan sesuatu, misalnya sebuah pintu tertutup, sebuah engsel, memberikan tekanan, mengoperasikan, dan lain-lain.

f. Semantik evaluatif (evaluative semantics): makna diperoleh dengan pembandingan, penilaian, tes, misalnya lebih berat daripada, lebih bagus daripada, bagus, kebiasaan, lebih efisien, dan lain-lain.

g. Semantik kultural/budaya (cultural semantics): makna diperoleh melalui pengalaman sosial, norma-norma, misalnya ritual, tradisi, bahasa, hukum, dan konvensi (kesepakatan umum), dan lain-lain.

Untuk memahami lebih lanjut penerapan pendekatan Burnette ini, saya akan mengambil contoh penerapannya dari sebuah workshop yang diselenggarakan di Istanbul Technical University (ITU) (Bagli, 2011). Workshop ini memang hanya diselenggarakan secara lokal di universitas tersebut tetapi hasilnya bisa digunakan untuk memahami lebih jelas penggunaan kategorisasi yang dirumuskan oleh Burnette itu dalam penelitian. Hasil penelitian semacam ini kemudian juga bisa dijadikan sebagai dasar untuk merancang kembali sebuah produk. Workshop ini melibatkan beberapa mahasiswa desain produk dan diselenggarakan dalam dua fase. Fase pertama adalah dalam bentuk penelitian dan fase kedua adalah dalam bentuk penggunaan hasil penelitian semantik itu untuk mendesain sebuah produk baru. Kalau tujuannya hanya melakukan penelitian, maka hanya fase pertama yang dikerjakan dan fase kedua tidak perlu dilakukan.

Fase pertama, sebuah penelitian, tiga kelompok mahasiswa dibentuk dan setiap kelompok terdiri dari dua mahasiswa (mahasiswa pewawancara dan mahasiswa yang menjawab wawancara). Sebelum workshop, mahasiswa-mahasiswa yang terlibat disuruh membaca dan memahami lebih dulu tujuh kategori semantik yang dirumuskan oleh Burnette di atas. Setiap mahasiswa yang diwawancarai membawa sebuah produk tertentu yang dijadikan sebagai bahan tanya-jawab dalam wawancara terkait dengan tujuh kategori tersebut. Mahasiswa kelompok pertama memilih produk jam tangan merek Levi, kelompok kedua memilih lingkaran kunci (key ring), dan kelompok ketiga memilih kotak logam (metal box). Untuk pembahasan dalam ruang terbatas ini, wawancara yang akan dibahas hanya wawancara yang berlangsung di keompok 1 karena hanya dijadikan sebagai contoh. Semua pertanyaan yang diajukan menyangkut tujuh kategori semantik yang telah dipaparkan sebelumnya (Bagli, 2011). Hasil 
wawancara kelompok 1 tersebut (jam tangan merek Levi's) adalah sebagai berikut:

Contoh respon mahasiswa (dia) yang diwawancarai (intisari ringkas dari kelompok pertama) (Bagli, 2011).

Semantik emosional: jam tangan tersebut berharga karena pemberian teman dia; dari sisi desain dan interface (tampilan antar muka sebuah produk) berguna; desain bagus dan minimal tanpa hiasan, sesuatu yang disukainya; interface juga sederhana; pada siang hari dari jam tangan tersebut muncul gambar bunga yang tumbuh; pada malam hari dari jam tangan tersebut muncul gambar bintang, dia sangat menyukai bintang.

Semantik empiris: jam tangan tersebut ringan, lunak, dan tidak menimbulkan keringat; jam itu demikian ringannya seolah-olah dia tidak memakainya di pergelangan tangan, ini juga disukainya.

Semantik kognat: baginya desain jam itu memiliki asosiasi abstrak dengan benda-benda lain, mirip dengan sebuah sabun merek terkenal; jam berwarna putih seperti sabun tersebut dan memiliki volume dan ukuran yang sama. Asosiasi ini positif baginya karena dia menyukai kebersihan. Menurut dia, membawa sabun dengan pergelangan tangan menyenangkan.

Semantik kontekstual: kalau sedang mengenakan jam itu, dia merasa menggunakannya dengan perasaan khusus; sebagai contoh, dia menggunakannya ketika jam itu cocok dengan pakaian yang dikenakannya; dia tidak mengenakan jam itu kalau sedang mengenakan pakaian dengan lengan panjang; pada waktu musim panas dia hanya mengenakan jam itu pada waktu malam karena pada waktu siang hari cahaya tidak cukup terang dan cuaca panas tidak nyaman.

Semantik fungsional: dia menggunakan jam itu terbatas waktunya, tetapi ketika mengenakan jam itu dia menggunakannya secara efektif karena jam itu memiliki interface dasar, mudah dibaca, ringan, dan tidak menyebabkan berkeringat; fitur lampu senter pada jam itu penting baginya dan menciptakan makna fungsional lain baginya; dia tidak suka mengenakan asesoris dan jam itu menjadi asesorinya.

Semantik evaluatif: berdasarkan perbandingan yang didasarkan pada penilaian, pengukuran, dan penaksiran, dia menganggap jam itu lebih ringan, lebih mudah dibaca, dan dalam hal kemampuan mencegah keluar keringat lebih baik dari jam-jam lain; sebetulnya dia tidak suka mengenakan jam tangan, tetapi karena jam ini berbeda, maka dia mengenakannya.

Semantik budaya: dia bukanlah orang yang 'sadar waktu', makanya dia tidak selalu mengenakannya dan segera melepas jam jika berkeringat; dia berpikir bahwa mengenakan jam tangan membikin stres karena dia selalu merasa perlu mengejar waktu dan harus selalu siap mengerjakan sesuatu; dia cenderung hidup dengan pemahaman tentang waktu sendiri; dia tidak selalu sadar waktu.

Dalam penelitian sesungguhnya, penelitian semantik semacam ini bisa mengambil sampel pengguna produk tertentu dalam jumlah banyak untuk mengetahui perubahan apa yang menurut mereka perlu dilakukan terhadap sebuah produk agar lebih baik dari sebelumnya menyangkut aspek fungsi dan bentuk. Jangka waktu penelitian bisa pendek atau panjang tergantung kompleksitas sebuah produk. Hasil penelitian ini kemudian digunakan sebagai dasar merancang kembali sebuah produk dengan berbagai variasinya, baik masih terkait dengan produk yang diteliti maupun produk-produk yang sama sekali baru. Adapun jenis produk yang diteliti bisa produk apa saja karena memang tujuannya untuk membuat produk yang diteliti bisa didesain kembali dengan hasil yang lebih baik sehingga diharapkan bisa disukai oleh lebih banyak pengguna.

Pendekatan kategorisasi semantik memiliki kelebihan sekaligus kekurangan. Pendekatan ini memiliki kelebihan karena kategori-kategori yang dilibatkan dalam pengumpulan dan analisis data banyak jumlahnya sehingga mempermudah upaya memenuhi persyaratan desain (design requirements) produk yang akan dirancang. Kelemahan pendekatan ini terletak pada ketidakmudahan penafsiran data karena sebagian besar data bersifat lualitatif dan dalam bentuk verbal sehingga perlu ditafsirkan secara tepat untuk mempermudah perancangan kembali produk.

\section{Pendekatan Semantik Diferensial}

Pendekatan semantik diferensial berakar pada semantik psikologis. Dalam psikologi, Osgood, Suci, dan Tannenbaum telah mengembangkan pengukuran makna dengan menggunakan teknik semantik diferensial sebagai bagian dari sebuah jenis psikosemantik (Nöth, 1995; Osgood, G.J., \& P.H., 1957). Dalam psikosemantik ini, konotasi ungkapan kata-kata subjektif yang dikemukakan oleh orang yang diteliti dianalisis. Ungkapan kata-kata ini dinilai menggunakan sebuah dimensi ruang semantik yang bertumpu pada kata-kata yang merupakan perlawanan semantik, misalnya 'baik' versus 'buruk,' 'keras' versus 'lunak', dan lain-lain.

Ada sebuah contoh menarik sebuah penelitian yang menerapkan pendekatan semantik diferensial, yaitu sebuah penelitian tentang furnitur jalanan (street furniture) berupa bangku duduk yang dilakukan oleh 
C. Maurer, C.J. Overbeeke, dan G. Smets di Alunalun Promenadeplein di kota Zoetermeer, Belanda (Maurer, Overbeeke, \& Smets, 1992). Promenadeplein adalah sebuah area pejalan kaki (pedestrian) yang dikelilingi oleh bangunan-bangunan yang dibuat pada abad 17 dan awal abad 18 . Bangunan-bangunan ini berfungsi sebagai toko serba ada, toko, kantor, dan apartemen. Penelitian ini sifatnya jangka pendek, sekitar dua minggu dan melibatkan 25 partisipan (14 perempuan dan 11 lakilaki). Para partisipan diberi insentif uang atas dasar persetujuan. Selain partisipan yang dibayar, ada juga partisipan yang memang telah duduk di bangku yang telah ditentukan. Penelitian dilakukan antara jam 11 pagi dan jam 3 sore. Adapun kata-kata yang digunakan, yang merupakan perlawanan semantik adalah sebagai berikut:

$\begin{aligned} \text { kuat } & >\text { rapuh } \\ \text { impresif } & >\text { kalem } \\ \text { ringan } & >\text { berat } \\ \text { publik } & >\text { privat } \\ \text { santai } & >\text { serius } \\ \text { industrial } & >\text { kerajinan tangan } \\ \text { tradisional } & >\text { modern } \\ \text { terbuka } & <\text { protektif } \\ \text { hangat } & <\text { dingin } \\ \text { kalem } & <\text { ramai } \\ \text { murah } & >\text { mahal } \\ \text { lunak } & >\text { keras } \\ \text { tak nyaman } & <\text { nyaman }\end{aligned}$

Pendekatan semantik diferensial ini kemudian dilengkapi dengan dua langkah lain, yaitu perbandingan bentuk-bentuk bangku yang diteliti menggunakan skala kesamaan/kebedaan $1-5$ (misalnya 1 = sama, 5 = tidak sama) dan preferensi (kecenderungan menyukai). Selain itu analisis yang dilakukan juga melibatkan ergonomi/kenyamanan dn keamanan, dan juga bahan. Analisis terhadap katakata yang merepresentasikan perlawanan semantik, perbandingan bentuk-bentuk bangku, dan skala kesamaan/kebedaan tentu saja harus dilakukan secara cermat sehingga menghasilkan temuan-temuan yang paling mendekati ideal.

Hasil penelitian memperlihatkan jenis-jenis bangku jalanan tertentu yang disukai oleh pengguna di area pedestrian Promedeplein di kota Zotermeer, Belanda. Hasil penelitian ini bisa digunakan untuk merancang kembali bangku-bangku jalanan yang ada di area pedestrian tersebut dan bahkan bisa digunakan sebagai bahan pertimbangan untuk merancang kembali bangku-bangku jalanan di kota-kota lain.

Pendekatan ini juga memiliki kelebihan dan kekurangan. Pendekatan ini memiliki kelebihan karena bisa memberi manfaat lebih besar jika dilakukan di lingkungan yang lebih besar dengan melibatkan jumlah produk dan partisipan yang lebih besar juga. Pendekatan ini juga bisa digunakan untuk meneliti berbagai jenis produk lain dengan melibatkan proses pembandingan antar produk sejenis sehingga akan dapat diketahui kekuatan dan kelemahan produk tertentu yang mempengaruhi pengguna atau konsumen. Dari sinilah kemudian dilakukan proses perancangan kembali produk. Kekurangan pendekatan ini terletak pada ketidakmudahan dalam mengumpulkan partisipan dalam jumlah besar dan mengikutsertakan mereka secara bersama. Contoh penelitian yang dilakukan di kota Zoetermeer tersebut tidak banyak melibatkan partisipan karena lingkup penelitian terbatas. Dalam lingkup penelitian yang lebih besar di sebuah kota, misalnya, pengerahan partisipan dalam jumlah besar tidaklah mudah.

\section{Pendekatan Netnografi}

Netnografi adalah metode penelitian yang dilakukan secara online menggunakan internet. Metode ini mulai dikembangkan pada tahun 1995 oleh Robert Kozinets, seorang profesor di Northwestern University, Amerika Serikat. Netnografi berbeda dengan etnografi karena dalam mengumpulkan data peneliti tidak melakukan tatap muka langsung dengan para partisipan. Dalam rangka memperoleh data, peneliti (bisa dibantu oleh orang lain) berkomunikasi dengan para partisipan melalui internet. Peneliti dapat menggunakan berbagai macam aplikasi di internet untuk mengumpulkan data penelitian sebanyak mungkin. Untuk memperoleh data yang banyak, peneliti harus pandai mendekati orang-orang yang akan dijadikan sebagai partisipan karena orang-orang tersebut sebagian besar tidak akan ditemuinya secara langsung. Sebagaimana dikatakan oleh Kozinets, miliaran orang bergabung dalam jaringan-jaringan, ambil bagian dalam sebuah dunia kompleks yang tidak hanya mencerminkan dan mengungkapkan pengalaman-pengalaman hidup mereka tetapi juga adalah fenomena sosial yang unik. Netnografi dapat membantu anda memahami dunia itu. Netnografi dapat membantu anda memahami berbagai konteks yang membuat pemahaman tentang dunia menjadi mungkin, juga tentang bentuk-bentuk sosial baru yang menggantikan dan bentuk-bentuk sosial lama yang digantikan (Kozinets, 2016).

Sebagai sebuah pendekatan yang relatif baru, netnografi semakin sering digunakan dalam penelitian 
berbagai ilmu, tidak terkecuali bidang desain. Menurut Kozinets, netnografi digunakan untuk mengadakan penelitian etnografi secara etis dan menyeluruh dengan melibatkan kerja kearsipan dan kerja komunikasi online, partisipasi dan observasi, dengan bentuk baru data digital dan jaringan, analisis, dan representasi penelitian (Kozinets, 2016). Peneliti yang menggunakan pendekatan netnografi, kata Kozinets, tidak hanya menggunakan kata-kata tetapi juga imaji, gambar, fotografi, data suara, presentasi audiovisual yang diedit, kreasi-kreasi website, dan artifak-artifak digital yang lain. Netnografi menyediakan panduan-panduan partisipatif, termasuk pendampingan melalui research web-page (halaman pemandu penelitian lewat jaringan internet), wawancara lewat Skype, dan kerja lapangan secara pribadi dalam rangka memindahkan kerja etnografi ke online media (Kozinets, 2016).

Pada tahun 1950-an, ketika komputer berukuran besar kebanyakan hanya dimiliki oleh perusahaanperusahaan dan pemerintah, metafora atau kiasan untuk komputer pada waktu itu adalah komputer sebagai 'otak raksasa.' Ketika komputer bisa dibuat dalam ukuran lebih kecil dan masuk ke rumah-rumah serta dihubungkan dengan jaringan internet, maka metafora untuk komputer pada masa sekarang, dalam konteks komunikasi, adalah 'maha-jalanraya informasi.' (information superhighway). Mark Stefik menyebut metafora 'maha-jalanraya informasi' mengandung empat metafora di dalamnya (Stefik, 1996):

a. Perpustakaan online (online library): sebuah tempat penyimpanan untuk menerbitkan dan menyimpan pengetahuan kolektif, sebuah bentuk komunal atau kolektif.

b. Medium Komunikasi-komunikasi digital (digital communications medium): sebuah tempat untuk surat elektronik (email) dan, pada akhirnya, banyak bentuk komunikasi lainnya.

c. Tempat pasar Elektronik (Electronic Marketplace): sebuah lokasi untuk transaksi barang dan jasa secara elektronik, termasuk perdagangan digital, uang digital, dan properti digital.

d. Dunia digital: sebuah pintu gerbang menuju pengalaman-pengalaman baru, termasuk tatanantatanan sosial baru, realitas maya (virtual reality) dan realitas tertambah (augmented reality), presentasi jarak jauh (telepresence), dan penggunaan layanan komputer di mana-mana (ubiquitous computing).
Salah satu contoh penerapan pendekatan netnografi adalah sebuah publikasi yang semula adalah sebuah tesis bidang desain produk yang dikerjakan oleh Bastian Evers di University of Twente, Belanda. Netnografi digunakan di sini untuk mengumpulkan data dalam rangka perancangan kembali (redesign) sepeda merek terkenal Gazelle yang akan dipasarkan di Amerika Serikat sehingga memerlukan data baru menyangkut preferensi para pengguna sepeda merek tersebut di Amerika Serikat. Lewat netnografi diharapkan muncul data tentang spesifikasi sepeda yang disukai oleh pengguna atau konsumen sepeda merek Gazelle di Amerika Serikat (Evers, 2016). Sepeda merek terkenal Gazelle dibuat di Belanda dengan lokasi pembuatannya di kota Dieren. Dahulu merek sepeda ini sangat terkenal di Indonesia dan termasuk jenis sepeda kelas tinggi yang hanya dimiliki oleh orang-orang tertentu. Hingga sekarang sepeda merek Gazelle tetap diproduksi dan dipasarkan di seluruh dunia, termasuk di Amerika Serikat.

Peneliti membagi sepeda menjadi empat jenis: sporty (untuk olah raga atau penjelajahan alam), family (untuk kegiatan dengan keluarga), utility (berbelanja, melihat sekitar), commuting (pergipulang dari dan tempat kerja). Penelitian ini memfokuskan diri pada sepeda jenis family dan utility. Alasan pemilihan dua jenis sepeda ini karena pengguna sepeda di Amerika Serikat terbatas, tidak sebanyak di Belanda. Untuk menjaring apa yang diinginkan oleh para pengguna sepeda merek Gazelle di Amerika Serikat menyangkut dua jenis sepeda tersebut, peneliti melakukan observasi online dengan mengajukan pertanyaan-pertanyaan dan memperoleh jawaban lewat situs online pengguna sepeda di Amerika Serikat yaitu bikeforums.net. Lewat forum ini peneliti menjaring pendapat para pengguna sepeda di Amerika Serikat menyangkut spesifikasi yang mereka sukai terkait dengan sepeda Gazelle jenis sporty dan utility. Setelah banyak pertanyaan terjawab serta pro dan kontra berlangsung, pada akhirnya diskusi dalam forum tersebut menghasilkan konsensus-konsensus yang kemudian akan dijadikan sebagai dasar untuk merancang kembali sepeda Gazelle jenis sporty dan utility yang akan dipasarkan di Amerika Serikat (Evers, 2016). Dalam penelitian yang tingkat akurasinya diharapkan lebih besar, karya re-desain yang telah dibuat kemudian diedarkan lagi ke para pengguna melalui penelitian netnografi kedua. Masukan dari para pengguna kemudian digunakan untuk merancang kembali sebuah produk yang sudah ada sebelumnya. Dengan cara ini diharapkan produk yang dibuat lewat re-desain menjadi semakin baik dan laku di pasaran. Tentu saja penelitian yang mencakup 
netnografi kedua akan memakan waktu, tetapi untuk sebuah penelitian tingkat lanjut, netnografi kedua ini tentu sangat menantang dan sangat berguna bagi pemasaran produk-produk konsumen.

Dalam konteks persaingan produk, tentu saja pendekatan penelitian ini juga dipengaruhi oleh keunggulan teknologi dan posisi branding dari sebuah produk beserta perusahaan yang membuatnya. Oleh karena itu produk-produk berkualitas dari sebuah perusahaan mapan yang selama ini mendominasi pasar tentu saja akan lebih diuntungkan dengan penelitian semacam ini. Sepeda Gazelle adalah produk yang telah mapan sejak waktu yang lama, sehingga penggunaan pendekatan penelitian ini kemungkinan besar akan semakin memperkokoh posisi produk ini.

Pendekatan netnografi memiliki kelebihan sekaligus kekurangan. Pendekatan ini memiliki kelebihan karena dalam mengumpulkan data peneliti tidak perlu turun ke lapangan menemui langsung para partisipan seperti dalam penelitian etnografi. Peneliti cukup mengajukan berbagai pertanyaan lewat internet, terutama terhadap orang-orang yang menjadi pengguna produk yang diteliti dan mereka bisa dilacak dan dihubungi di media sosial lewat komunitas pengguna produk tersebut. Kelemahan pendekatan ini justru melekat pada kelebihannya karena pertanyaan-pertanyaan yang diajukan lewat media sosial tentu tidak dengan cepat dijawab oleh partisipan dan jawaban yang diberikan kemungkinan tidak mendetail sehingga pertanyaan perlu diulang. Penelitian lewat internet akan efektif jika jalinan komunitas pengguna produk yang diteliti di internet kuat dan mereka sering melakukan komunikasi bersama lewat situs yang dibangun oleh perusahaan pembuat produk tersebut.

\section{Kesimpulan}

Tulisan ini membahas tiga pendekatan yang bisa digunakan untuk melakukan penelitian dalam rangka merancang kembali sebuah produk agar lebih berkualitas, termasuk di dalamnya lebih ramah terhadap lingkungan. Tiga pendekatan tersebut adalah kategorisasi semantik, semantik diferensial, dan netnografi. Ketiga pendekatan ini tidak sepenuhnya berhubungan karena pendekatan netnografi biasanya dibicarakan dalam kaitan dengan pendekatan etnografi, tidak dalam kaitan dengan semantik. Meskipun begitu ketiganya bisa digunakan untuk tujuan yang sama sehingga dibahas bersama dalam tulisan ini. Masing-masing pendekatan ini memiliki kelebihan dan kekurangan, tetapi dengan analisis yang tajam ketiga pendekatan ini bisa dimanfaatkan dalam penelitian yang digunakan untuk merancang kembali sebuah produk.

\section{Daftar pustaka}

Bagli, H. (2011). Product Semantics Meets the User: A Design Workshop with a Fresh Look to an Old Paradigm. Istanbul Technical University $A \mid Z, 8(2)$.

Burnette, C. (1994). Designing products to afford meanings. Design-Pleasure or Responsibility, 120-125.

Evers, B. (2016). Gazelle Success in the United States of America Design Thinking. University of Twente.

Kozinets, R. V. (2016). Netnography: Redefined, second edition. Los Angeles: SAGE Publications, Inc.

Maurer, C., Overbeeke, C. J., \& Smets, G. (1992). The Semantics of Street Furniture. In S. Vihma (Ed.), Objects and Images. Helsinki: University of Industrial Arts.

Nöth, W. (1995). Handbook of semiotics. Bloomington: Indiana University Press.

Osgood, C. E., G.J., S., \& P.H., T. (1957). The Measurement of Meaning. Urbana: University of Illinois Press.

Stefik, M. (1996). Internet Dreams. Boston: MIT Press.

Zoest, A. van. (1993). Semiotika: Tentang Tanda, Cara Kerjanya, dan Apa yang Kita Lakukan Dengannya. Jakarta: Yayasan Sumber Agung. 